University of Nebraska - Lincoln

DigitalCommons@University of Nebraska - Lincoln

Faculty Publications, UNL Libraries

Libraries at University of Nebraska-Lincoln

12-1-1991

Spreadsheet Models for Cataloging Statistics

Mary K. Bolin

University of Nebraska--Lincoln, mbolin2@unl.edu

Follow this and additional works at: https://digitalcommons.unl.edu/libraryscience

Part of the Library and Information Science Commons

Bolin, Mary K., "Spreadsheet Models for Cataloging Statistics" (1991). Faculty Publications, UNL Libraries. 49.

https://digitalcommons.unl.edu/libraryscience/49

This Article is brought to you for free and open access by the Libraries at University of Nebraska-Lincoln at DigitalCommons@University of Nebraska - Lincoln. It has been accepted for inclusion in Faculty Publications, UNL Libraries by an authorized administrator of DigitalCommons@University of Nebraska - Lincoln. 


\title{
Spreadsheet Models for Cataloging Statistics
}

\author{
Mary K. Bolin
}

\begin{abstract}
Statistics about cataloging activity are collected for several reasons: to monitor productivity and workflow and to satisfy requests from outside agencies and the library administration about the size and nature of the library's collection. Several spreadsheets developed at the University of Idaho Library to collect statistics about cataloging activity and technical services activity and costs are examined here.
\end{abstract}

Although our effectiveness is hard to measure, librarians and library staff are concerned about how good a job we are doing. At the University of Idaho (UI) library, in common with most libraries, one thing we do to monitor our performance is to keep statistics about our activities. Statistics serve many purposes, and what is appropriate for one institution may be of no use to another. Moreover, there is often a strong but hard-to-discern historical reason for keeping certain statistics which makes it hard for a library to distinguish gathering essential information from mere habit. Nevertheless, sharing information about statistics-keeping is useful for distinguishing the essential from the habitual.

Although library literature includes information about library data collection, ${ }^{1}$ spreadsheet models for library use, ${ }^{2}$ and the cost of technical services in particular, ${ }^{3}$ little or nothing has been written specifically about what data is collected regarding cataloging pro-

Mary K. Bolin is Head of the Cataloging Department at the University of Idaho in Moscow. She holds a Bachelor's Degree from the University of Nebraska and a Master of Science Degree in Library Science from the University of Kentucky.

Technical Services Quarterly, Vol. 8(4) 1991

(c) 1991 by The Haworth Press, Inc. All rights reserved. 
duction or cost. ${ }^{4}$ While the kinds of statistics traditionally collected about cataloging are generally straightforward accounts of how many items were cataloged in a given period broken down into various categories by format and by the tasks which make up cataloging, this information can be the basis for planning and decisionmaking about staffing, budgeting and workflow. ${ }^{5}$

The Cataloging Department of the UI library collects statistics for several purposes. The first is to keep track of how many volumes are added to the library's collections and in what areas. A second reason is to monitor workflow and productivity within the department. A third purpose is to review the amount of money spent for each function (including cataloging) provided by the Western Library Network (WLN), the library's bibliographic utility.

A number of different electronic spreadsheet programs have been used to keep cataloging statistics. Up until the mid-1980s statistics were kept by hand and calculator. In about 1984, we began to use one of the early VisiCalc-type spreadsheets such as PC-Calc and ExpressCalc. This was revolutionary at the time, and made it much easier to store, compare and print statistical data about cataloging. The technique used to create a monthly departmental spreadsheet, however, was to gather statistics reported by individuals and add the total for each area of the classification schedule by hand before entering the total into the spreadsheet.

In 1987, we began using Silk, a much more powerful package, quite similar to Lotus 1-2-3, and able to import and export Lotus files. While the cataloging department has successfully used a spreadsheet which is similar to Lotus and can import and export Lotus files but not read and write them directly, it would have been better to have bought a copy of Lotus for the department. Using a non-standard file format has required extra effort in order to give someone a file on a disk, and we have not been able to use any of the commercial, shareware and public domain Lotus add-ins, templates and macros which have been developed.

We have developed several different spreadsheet models to accomplish the purposes described above. None of these uses more than the four basic arithmetic functions to analyze the data. Nevertheless, the information is useful for decision-making about staffing, performance appraisal, budgeting and collection analysis. The 
first model is a conventional monthly cataloging total which has been in use for about five years, and is based on the form which was used when all statistics keeping was done manually. It shows numbers of titles cataloged and total number of volumes added in call numbers A-Z, in each area of the library's Special Collections (materials of local interest), and in each format such as computer files, sound recordings, microforms, etc. It keeps separate counts of monographs and serials, and of original and copy cataloging.

Totals in the columns for original, adaptive (records found in RLIN and retagged for inputting into WLN, or WLN records for similar items), database (copy cataloging) and serials cataloging feed into the "total cataloged" column. Added volumes and copies are combined with those totals, and items which have been lost or withdrawn are subtracted to arrive at the total added each month.

Each person in the department still keeps a monthly statistics sheet, but totals for individuals are no longer added by hand to reach a departmental total (see Figure 2). The monthly spreadsheet also includes a column for each person, with multiple columns for people who do both copy and original cataloging. There is also a separate column for each person's added copies and volumes. Each of these columns feeds into the summary section (Figure 1) which is eventually printed and shared with the department and the rest of the library.

These separate monthly spreadsheets are saved in individual files, but the monthly spreadsheet is also one part of the broader technical services statistics spreadsheet. The most important purpose of that spreadsheet is to show how many volumes are added each fiscal year. Cataloging totals for each month are imported into the technical services spreadsheet. Volumes added automatically update a table which shows volumes added month by month. The total volumes column in the monthly spreadsheet in Figure 1 feeds into the appropriate volumes column in Figure 3, each time the new month is imported into the technical services spreadsheet. The figures in the "bound volumes" column are supplied at the end of the year by the serials department, and are subtracted from the total.

These monthly volume totals cumulate and are also added to another table which shows total volumes already in the library at the beginning of the fiscal year, how many have been added thus far, 
FIGURE 1. Cataloging Department Statistics FY89/90: January 1990 DATA-

ADAP- DATA- ORIG. BASE TOT, LOSTE ADDED TOTAL CLASS. ORIG. TIVE BASE SER. SER. CAT. W'DRN COP/VOL VOLUMES

\begin{tabular}{|c|c|c|c|c|c|c|c|c|}
\hline $\mathbf{A}$ & 0 & 0 & 0 & & & 0 & 8 & 8 \\
\hline B & 0 & 1 & 33 & & & 34 & 0 & 34 \\
\hline$c$ & 0 & 0 & 2 & & & 2 & 0 & 2 \\
\hline D & 0 & 3 & 54 & & & 57 & 13 & 70 \\
\hline $\mathbf{E}$ & 0 & 6 & 21 & & & 27 & 3 & 30 \\
\hline$F$ & 1 & 1 & 20 & & & 22 & 6 & 28 \\
\hline G & 2 & 0 & 17 & & & 19 & 8 & 27 \\
\hline $\mathrm{E}-\mathrm{HJ}$ & 3 & 1 & 86 & & 3 & 93 & 46 & 139 \\
\hline $\mathrm{HM}-\mathrm{HX}$ & 0 & 1 & 52 & & & 53 & 6 & 59 \\
\hline $\mathrm{J}$ & 0 & 1 & 30 & & & 31 & 6 & 37 \\
\hline $\mathrm{x}$ & 0 & 0 & 4 & & 1 & 5 & 4 & 9 \\
\hline L & 0 & 0 & 11 & & & 11 & 4 & 15 \\
\hline $\mathbf{M}$ & 39 & 15 & 29 & & & 83 & 2 & 85 \\
\hline $\mathbf{N}$ & 17 & 2 & 46 & & & 65 & 4 & 69 \\
\hline $\mathbf{P}$ & 53 & 1 & 180 & 1 & & 235 & 41 & 276 \\
\hline$Q$ & 5 & 14 & 76 & & & 95 & 76 & 271 \\
\hline $\mathbf{R}$ & 7 & 1 & 15 & & & 23 & 8 & 31 \\
\hline $\mathbf{S}$ & 6 & 4 & 18 & 1 & & 29 & 59 & 88 \\
\hline $\mathrm{I}$ & 6 & 5 & 48 & & & 59 & 42 & 101 \\
\hline $\mathrm{U}-\mathrm{V}$ & 0 & 0 & 5 & & & 5 & 0 & 5 \\
\hline 2 & 0 & 0 & 4 & & & 4 & 5 & 9 \\
\hline TOTAL & 139 & 56 & 751 & 2 & 4 & 952 & 341 & $0 \quad 1,293$ \\
\hline
\end{tabular}

SPECIAL COLLECTIONS :

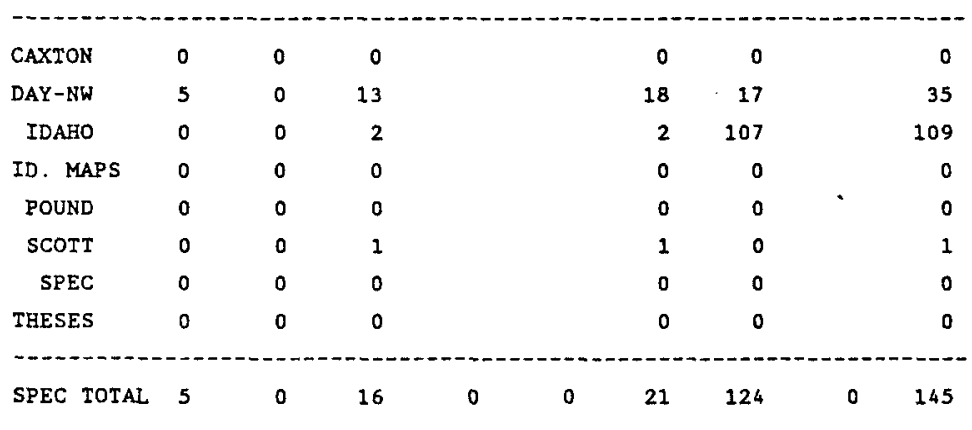


FIGURE 1 (continued)

AUDTOVISUAL:

\begin{tabular}{|c|c|c|c|c|c|c|c|c|c|}
\hline CLASS. & & $\begin{array}{l}\text { ADAP- } \\
\text { TIVE }\end{array}$ & $\begin{array}{l}\text { DAIA- } \\
\text { BASE }\end{array}$ & $\begin{array}{l}\text { ORIG. } \\
\text { SER. }\end{array}$ & $\begin{array}{l}\text { DATA- } \\
\text { BASE } \\
\text { SER. }\end{array}$ & $\begin{array}{l}\text { TOT. } \\
\text { CAT. }\end{array}$ & $\begin{array}{l}\text { LOST\& } \\
\text { W'DRN }\end{array}$ & $\begin{array}{l}\text { ADDED } \\
\text { COP / VOL }\end{array}$ & $\begin{array}{l}\text { TOT. } \\
\text { VOL. }\end{array}$ \\
\hline \multicolumn{10}{|c|}{ - } \\
\hline BROWSING & 0 & 0 & 14 & & & 14 & 0 & & 14 \\
\hline$C D^{\prime} s$ & 0 & 0 & 3 & & & 3 & 0 & & 3 \\
\hline CASSETTES & 0 & 0 & 0 & & & 0 & 0 & & 0 \\
\hline PHONODISC & 0 & 0 & 0 & & & 0 & 0 & & 0 \\
\hline RITS & 0 & 0 & 0 & & & 0 & 0 & & 0 \\
\hline MANUSCRIPTS & 0 & 0 & 0 & & & 0 & 0 & & 0 \\
\hline MAPS & 0 & 0 & 0 & & & 0 & 0 & & 0 \\
\hline COMP. FILES & 0 & 0 & 0 & & & 0 & 0 & & 0 \\
\hline VIDEOS & 0 & 0 & 0 & & & 0 & 0 & & 0 \\
\hline DOCUMENTS & 0 & 1 & 0 & & & 1 & 0 & & 1 \\
\hline AV TOTAL & 0 & 1 & 17 & 0 & 0 & 18 & 0 & 0 & 18 \\
\hline
\end{tabular}

MICROFORMS :

\begin{tabular}{|c|c|c|c|c|c|c|c|c|}
\hline FICHE-1ST & 0 & 0 & 0 & & & 0 & 0 & 0 \\
\hline FICHE-2ND & 0 & 0 & 0 & & & 0 & 1,110 & 1,110 \\
\hline FICHE-3RD & 0 & 0 & 0 & & & 0 & 0 & 0 \\
\hline FILM-1ST & 0 & 0 & 0 & & & 0 & 0 & 0 \\
\hline FILM-2ND & 0 & 0 & 0 & & & 0 & 0 & 0 \\
\hline FILM-3RD & 0 & 0 & 0 & & & 0 & 0 & 0 \\
\hline TOT. MFMS & 0 & 0 & 0 & 0 & 0 & 0 & 1,110 & $0 \quad 1,110$ \\
\hline
\end{tabular}

current new total, and what percentage of the library collection is represented by each location or call number (see Figure 4). There is also a section for acquisitions activity - items ordered and received (see Figure 5).

Another spreadsheet which shows cataloging activity is the cataloging workflow spreadsheet. As its name implies, its purpose is to show activities which contribute to the department's workload but not necessarily to the library's volume count. It includes a month- 
FIGURE 2. Monthly Totals for Individuals Copy

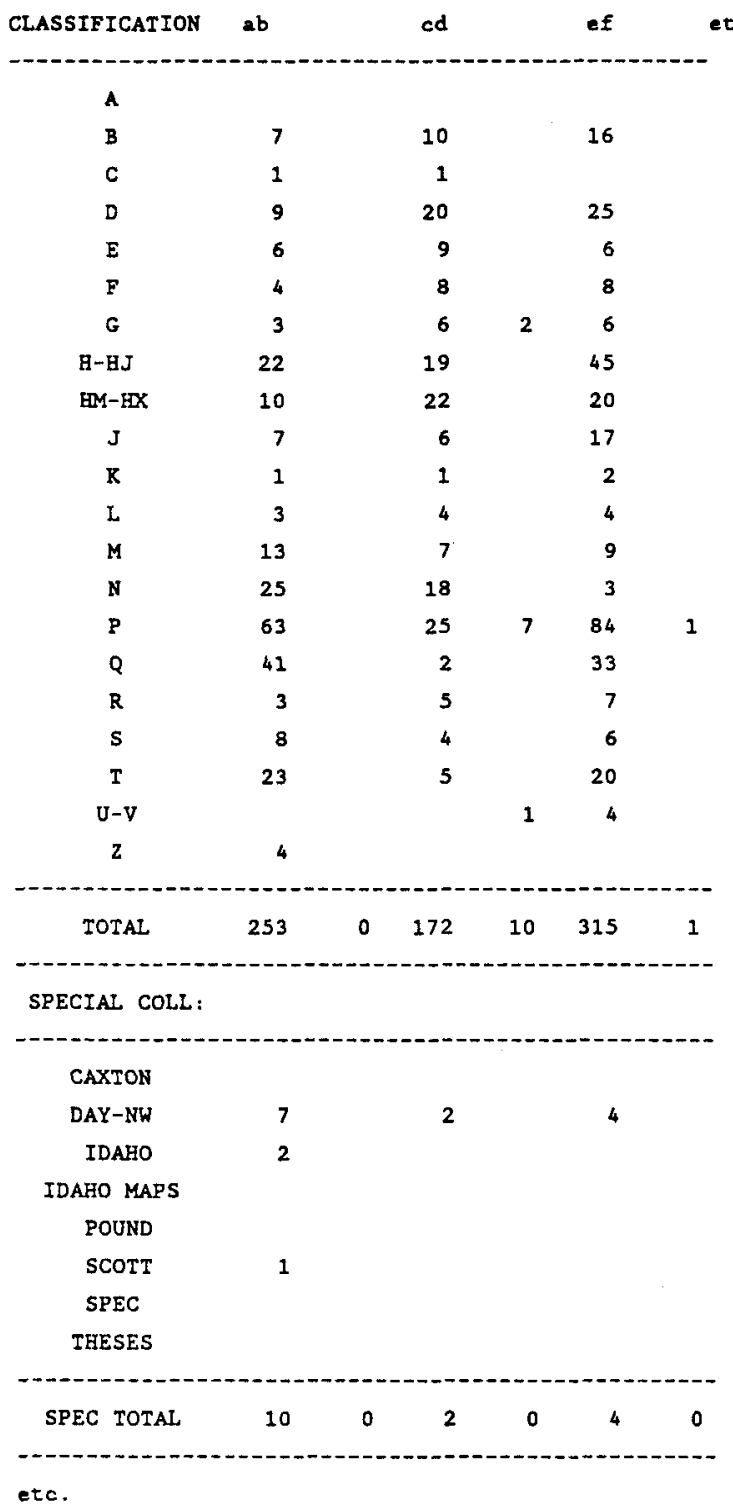


by-month summary of original and copy cataloging, WLN activity, and other activities which are not "new" cataloging and therefore cannot be counted on the spreadsheet which represents volumes added, as well as miscellaneous tasks such as recataloging, changes to database records, items classified. Most serials cataloging activity is reflected here, since so much serials cataloging is recataloging ("old serials and periodicals" in Figure 6), and also because the library counts new serial titles as they are cataloged, but does not count periodicals until they are bound.

An additional spreadsheet was developed in 1989 to help monitor the WLN budget and activity. This spreadsheet has subtotals for each area which uses WLN - cataloging, acquisitions, ILL, as well as products such as WLN's CD-ROM catalog LaserCat, and telecommunications charges (see Figure 7). The amounts from each monthly invoice are transferred to this spreadsheet in order to see more clearly where the money is being spent. Terminals are generally dedicated to only one activity, which makes it easy to divide the maintenance and terminal connect charges. Charges for inquiries are arbitrarily divided among the functional areas according to the number of terminals each has, even though cataloging undoubtedly does more searching per terminal than ILL, for example. The data in this spreadsheet are valuable for automation planning, since it is possible to see approximately how much money could be dedicated to an online system with some of the capabilities now supplied by a utility.

While these models have been refined over time and are generally adequate for gathering useful information, and while it is not particularly cumbersome or time-consuming to work with them, the models are not perfect, and are sometimes limited by habit or by the capabilities of the software. Although it is useful to have individual monthly spreadsheets which show activity for the department and for individuals, it would also be useful to see a running total for each person, such as the running volumes-added total which is part of the large technical services spreadsheet. A three-dimensional spreadsheet, or one with the ability to link worksheets, would accomplish this end. While some data is transferred from one worksheet to another, some rekeying is also necessary. Summary data from monthly cataloging statistics is keyed into the cataloging 
FIGURE 3. Volumes Added, Fiscal Year: $89 / 90$

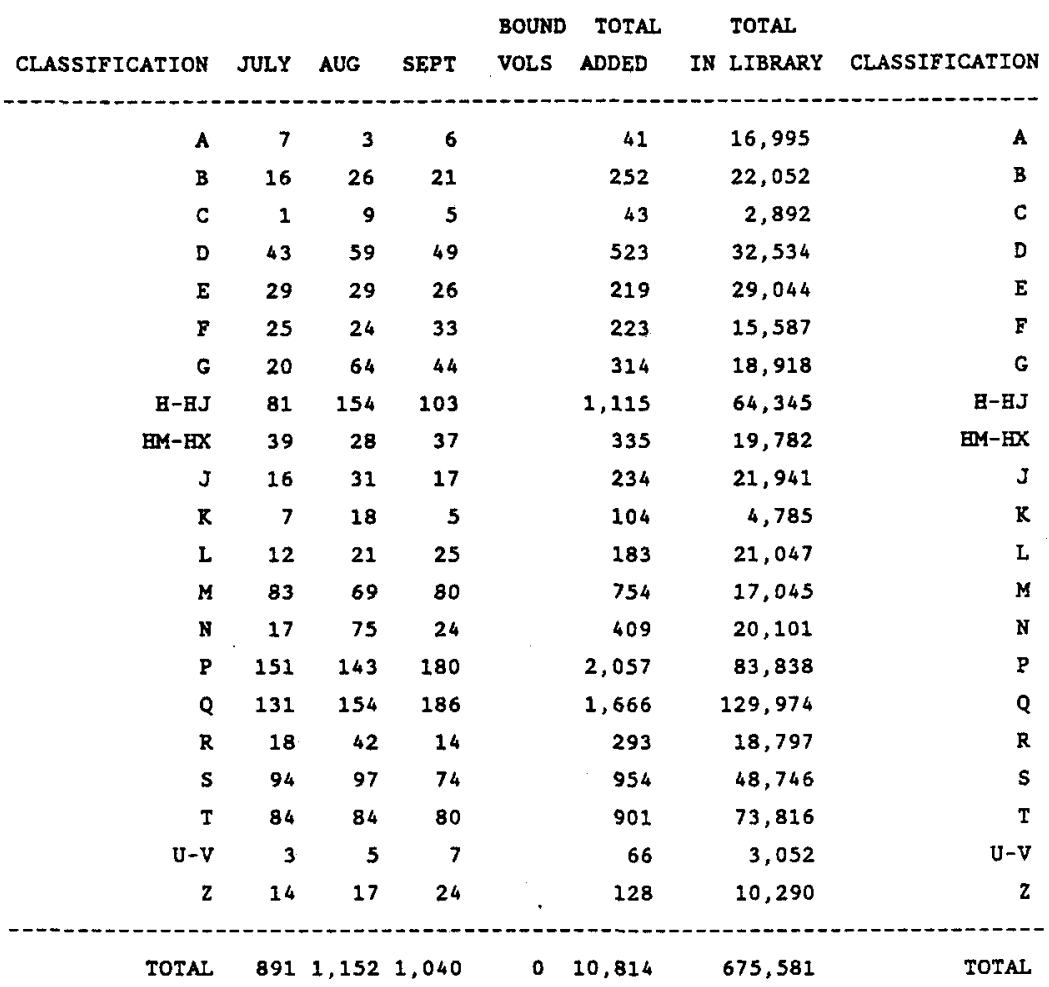

SPECIAL COLL:

SPECIAL COLL:

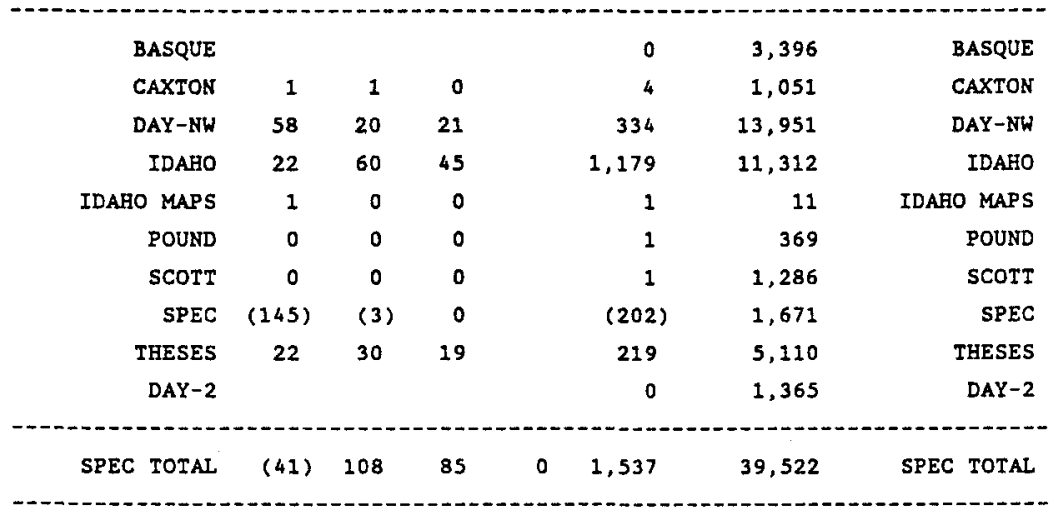


AUDIOVISUAL AND OTHER:

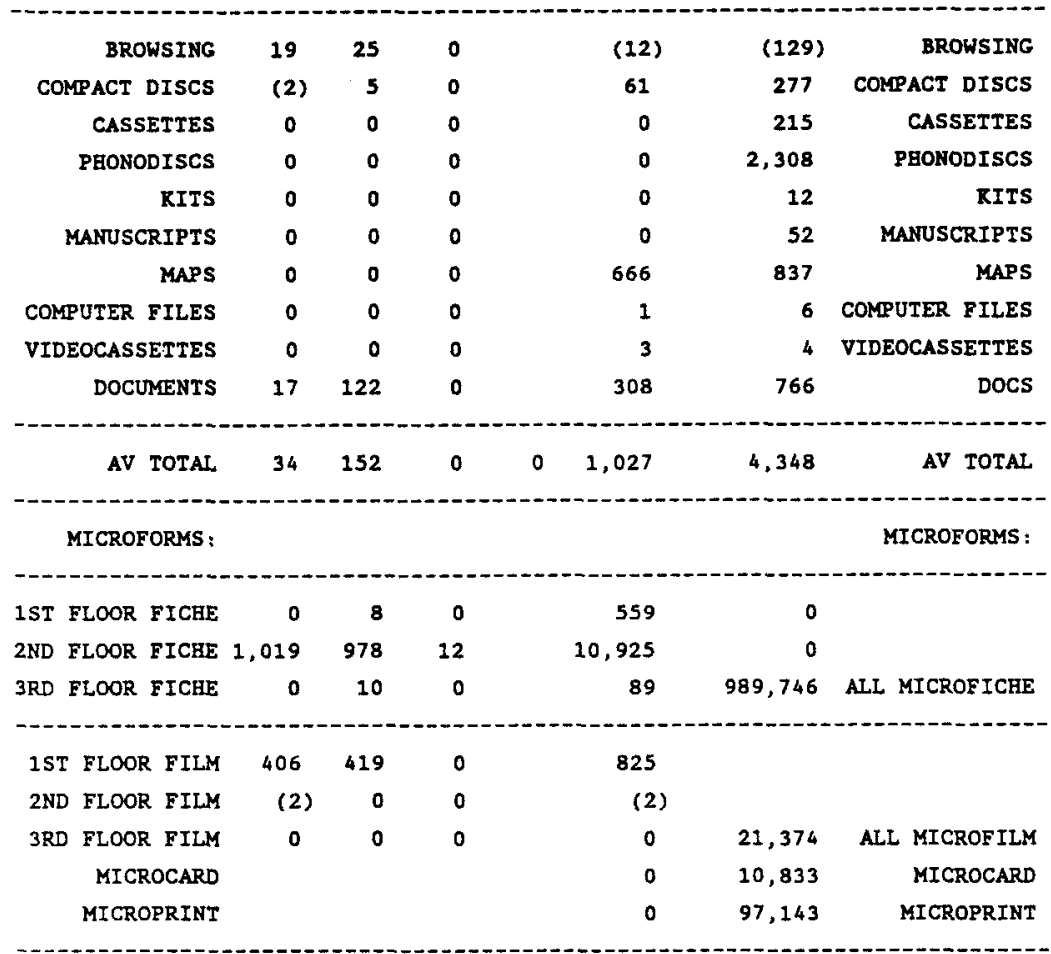

TOTAL MICROFORMS1,423 $1,415 \quad 12$ O $12,396 \quad 1,119,096$ TOTAL MICROFORMS

TOTAL VOLUMES $2,3072,827 \quad 1,137$ O $25,774 \quad 1,838,547$ TOTAL VOLUMES

workflow spreadsheet, for example, rather than being linked or imported. It would be easier to create the WLN cost data spreadsheet if the monthly invoice from WLN came on disk, in a .WKS file, for example, rather than only in its present paper form. Another software (and hardware) limitation is that spreadsheets are limited in size by available memory. Most library machines are still IBM-PCs or PC-XTs with $640 \mathrm{~K}$ memory, which are not always able to manipulate a very large spreadsheet. The technical services spreadsheet, for example, is more than 100,000 bytes long, and it is nec- 
FIGURE 4. Comparative Table

\begin{tabular}{|c|c|c|c|}
\hline CLASSIFICATION & $\begin{array}{l}\text { TOTAL VOLUMES } \\
\text { AS OF } 7-1-89\end{array}$ & $\begin{array}{l}\text { POL.UMES ADDED } \\
\text { FY89/90 }\end{array}$ & $\begin{array}{l}\text { TOTAL POLORES } \\
\text { AS OF } 7-1-90\end{array}$ \\
\hline$A$ & 16,995 & 41 & 17,036 \\
\hline B & 22,052 & 252 & 22,304 \\
\hline C & 2,892 & 43 & 2,935 \\
\hline D & 32,534 & 523 & 33,057 \\
\hline $\mathbf{E}$ & 29,044 & 219 & 29,263 \\
\hline $\mathbf{E}$ & 15,587 & 223 & 15,810 \\
\hline G & 18,918 & 314 & 19,232 \\
\hline B-EJ & 64,345 & 1,115 & 65,460 \\
\hline $\mathrm{BM}-\mathrm{EX}$ & 19,782 & 335 & 20,117 \\
\hline $\mathrm{J}$ & 21,941 & 234 & 22,175 \\
\hline $\mathbf{R}$ & 4,785 & 104 & 4,889 \\
\hline L & 21,047 & 183 & 21,230 \\
\hline$M$ & 17,045 & 754 & 17,799 \\
\hline $\mathrm{N}$ & 20,101 & 409 & 20,510 \\
\hline$P$ & 83,838 & 2,057 & 85,895 \\
\hline$Q$ & 129,974 & 1,666 & 131,640 \\
\hline $\mathbf{R}$ & 18,797 & 293 & 19,090 \\
\hline $\mathbf{s}$ & 48,746 & 954 & 49,700 \\
\hline $\mathrm{T}$ & 73,816 & 901 & 74,717 \\
\hline$U-\mathrm{v}$ & 3,052 & 66 & 3,118 \\
\hline$z$ & 10,290 & 128 & 10,418 \\
\hline TOTAL & 675,581 & 10,814 & 686,395 \\
\hline
\end{tabular}

etc.

essary to remove memory-resident programs such as Sidekick before loading it.

The other limitation to the usefulness of cataloging spreadsheets is a more subtle one. It is hard to develop a model which is free from unnecessary but historical categories, and which includes everything which is important to us without being burdensome to collect. Even if a library makes the effort to periodically re-examine statistical categories, it is easier to add new categories than to stop collecting data which has been kept for years.

The various reasons for keeping cataloging statistics are obvious from the kinds of spreadsheet models described above. The most 
FIGURE 5. Serials/Acquisitions

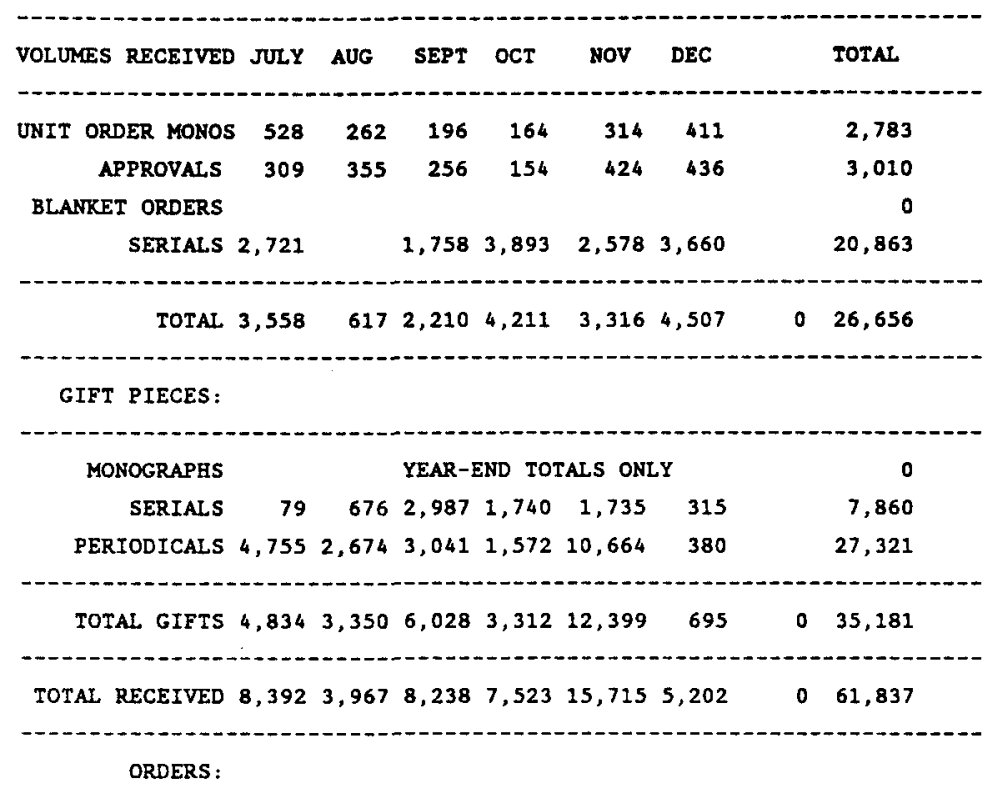

UNIT ORDERS:

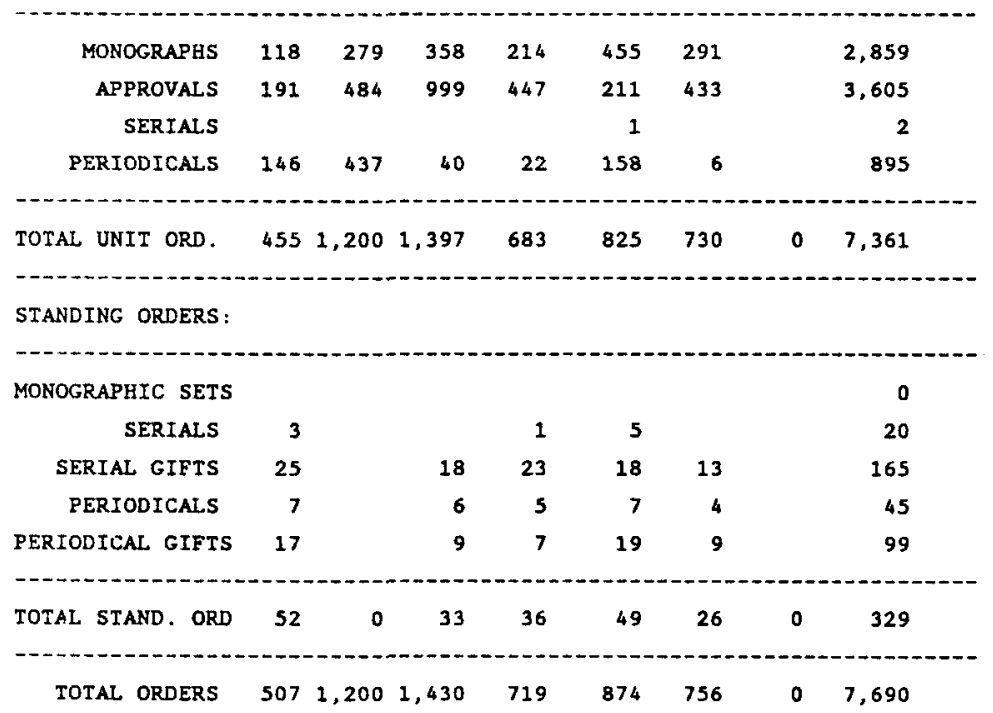


FIGURE 6. Cataloging Dept. Annual Workflow Statistics

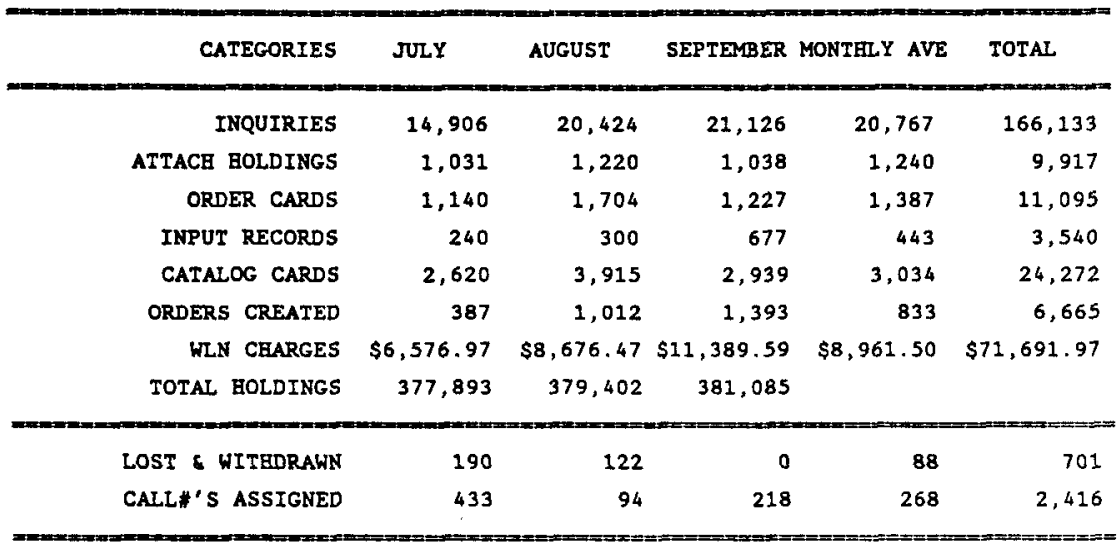

ORIGINAL CATALOGING :

\begin{tabular}{|c|c|c|c|c|c|c|}
\hline & MONOGRAPES & 147 & 145 & 216 & 253 & 2,279 \\
\hline NEW & SERIALS/PERIODICALS & 32 & 50 & 22 & 19 & 175 \\
\hline \multirow[t]{3}{*}{ OLD } & SERIALS / PERIODICALS & 6 & 2 & 5 & 4 & 21 \\
\hline & ANALYTICS & 7 & & 23 & 13 & 103 \\
\hline & TOTAL ORIGINAL & 192 & 197 & 265 & 289 & 2,578 \\
\hline \multicolumn{7}{|c|}{ DATABASE COPY: } \\
\hline & MONOGRAPHS & 633 & 989 & 733 & 915 & 8,237 \\
\hline NEW & SERIALS / PERIODICALS & 10 & 26 & 14 & 22 & 176 \\
\hline \multirow[t]{3}{*}{ OLD } & SERIALS/PERIODICALS & 59 & & 1 & 30 & 60 \\
\hline & ANALYTICS & 26 & 20 & 54 & 66 & 590 \\
\hline & IOTAL DATABASE & 728 & 1,035 & 802 & 1,033 & 9,063 \\
\hline & TOTAL CATALOGED & 920 & 1,232 & 1,068 & 1,322 & 11,641 \\
\hline
\end{tabular}

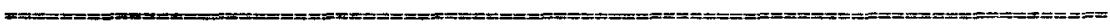

CHANGES TO DATABASE RECORDS :

$\begin{array}{llllll}\text { MONOGRAPRS } & 16 & 16 & 49 & 19 & 173\end{array}$

SERIALS / PERIODICALS

$\begin{array}{lllll}13 & 12 & 13 & 17 & 154\end{array}$

ANALYTICS

CIP's

3

$\begin{array}{llll}21 & 17 & 20 & 178\end{array}$

TOTAL CHANGES

35

49

79

58

510

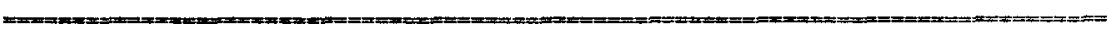


FIGURE 7. WLN Monthly Cost Breakdown by Function and Product, Fiscal Year $89 / 90$

$\begin{array}{rrrrrr}\text { MONTH: } & \mathrm{Jul} / 89 & \text { Aug/89 } & \text { Sep/89 } & \text { AVIRAGE } & \text { PY TOTAL } \\ \text { CATALOGING } & & & & & \\ \text { INQUIRIES } & \$ 2,024.30 & \$ 2,689.73 & \$ 2,779.60 & \$ 2,862.95 & \$ 28,629.48 \\ \text { ATTACE HOLDINGS } & \$ 309.30 & \$ 366.00 & \$ 311.40 & \$ 381.99 & \$ 3,819.90 \\ \text { RCP CORDER CARDS) } & \$ 171.00 & \$ 252.30 & \$ 184.05 & \$ 202.98 & \$ 2,029.80 \\ \text { INPUT NEW RECORDS } & \$ 52.80 & \$ 76.50 & \$ 125.00 & \$ 109.62 & \$ 1,096.20 \\ \text { WLN RECON INPUT } & \$ 224.50 & \$ 0.00 & \$ 1,125.70 & \$ 458.00 & \$ 2,748.00 \\ \text { CATALOG CARDS } & \$ 209.60 & \$ 309.76 & \$ 235.12 & \$ 226.60 & \$ 2,266.00 \\ \text { TERMINAL MAINTENANCE } & \$ 125.00 & \$ 125.00 & \$ 125.00 & \$ 125.00 & \$ 1,250.00 \\ \text { TERMINAL CONNECT CEARGE } & \$ 1,000.00 & \$ 1,000.00 & \$ 1,000.00 & \$ 1,000.00 & \$ 10,000.00\end{array}$

CATALOGING TOTAL $\$ 4,116.50 \quad \$ 4,819.29 \quad \$ 5,885.87 \quad \$ 4,236.62 \quad \$ 50,839.38$

\begin{tabular}{|c|c|c|c|c|c|}
\hline ILL: & & & & & \\
\hline INQUIRIES & $\$ 404.86$ & $\$ 538.87$ & $\$ 555.92$ & $\$ 572.68$ & $\$ 5,726.82$ \\
\hline ILL REQUESTS & $\$ 143.00$ & $\$ 157.30$ & $\$ 183.30$ & $\$ 218.79$ & $\$ 2,187.90$ \\
\hline ILL LOANS & $(\$ 52.25)$ & $(\$ 66.00)$ & $(\$ 64.25)$ & $(\$ 85.60)$ & $(\$ 856.00$ \\
\hline REPORTS & $\$ 88.61$ & $\$ 0.00$ & $\$ 0.00$ & $\$ 47.19$ & $\$ 377.55$ \\
\hline TERMINAL MAINTENANCE & $\$ 25.00$ & $\$ 25.00$ & $\$ 25.00$ & $\$ 25.00$ & $\$ 250.00$ \\
\hline TERMINAL CONNECT CHARGE & $\$ 200.00$ & $\$ 200.00$ & $\$ 200.00$ & $\$ 200.00$ & $\$ 2,000,00$ \\
\hline ILL TOTAL & $\$ 809.22$ & $\$ 855.17$ & $\$ 899.97$ & $\$ 807.19$ & $\$ 9,686.27$ \\
\hline ACQUISITIONS : & & & & & \\
\hline INQUIRIES & $\$ 404.86$ & $\$ 538.87$ & $\$ 555.92$ & $\$ 572.68$ & $\$ 5,726.82$ \\
\hline ORDERS & $\$ 522.30$ & $\$ 1,380.40$ & $\$ 1,866.85$ & $\$ 1,210.75$ & $\$ 12,107.45$ \\
\hline REPORTS & $\$ 489.09$ & $\$ 472.29$ & $\$ 346.53$ & $\$ 750.13$ & $\$ 7,501.33$ \\
\hline TERMINAL MAINTENANCE & $\$ 25.00$ & $\$ 25.00$ & $\$ 25.00$ & $\$ 25.00$ & $\$ 250.00$ \\
\hline TERMINAL CONNECT CEARGE & $\$ 200.00$ & $\$ 200.00$ & $\$ 200.00$ & $\$ 200.00$ & $\$ 2,000.00$ \\
\hline
\end{tabular}

ACQUISITIONS IOTAL $\$ 1,641.25 \quad \$ 2,616.56 \quad \$ 2,994.30 \quad \$ 2,298.80 \quad \$ 27,585.60$

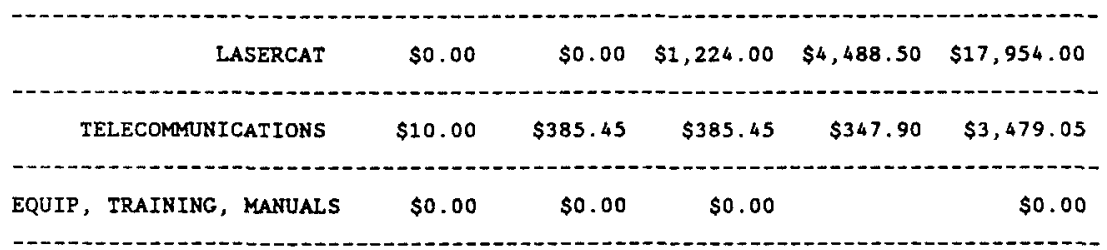

MONTHLY TOTAL $\$ 6,576.97 \$ 8,676.47 \$ 11,389.59 \$ 9,128.69 \$ 109,544.30$ 
important, although not necessarily from the point of view of those in the cataloging department, is that statistics on the size and nature of the library's collection are requested by the library administration and by outside agencies such as ACRL. These figures allow us to compare ourselves to our peer institutions and give a general idea of strengths and weaknesses in the collection.

The second reason for keeping statistics is more important to the cataloging department itself, and that is to monitor the productivity of individuals and of cataloging as a whole. This brings up a weakness with nearly any system of keeping cataloging statistics, and a controversial aspect of the whole process. Some people feel threatened by the idea of measuring their productivity in this sometimes crude and arbitrary way. They may feel that a gross count of certain tasks is a too easy and convenient way of judging them which may not reflect a true picture of their productivity, since inevitably not all tasks are counted, and since there is no explicit way of measuring difficulty of the task or quality of the result. Managerial staff must balance the time it takes to record, compile and interpret statistics against the need for the information and the need of staff to have their activities reflected in a tangible way.

\section{REFERENCES}

1. In addition to publications such as the ARL statistics, (Washington, D.C.: Association of Research Libraries, 1974/75-), some recent articles on this topic include a reprint of the influential 1965 study, Clapp, V.W. and Jordan, R.T., "Quantitative criteria for adequacy of academic library collections," College and Research Libraries 50:154-63, March 1989.

2. For a discussion of how to use a spreadsheet and models for library budget preparation, fund allocation, shelving capacity, employee scheduling, collection activity, etc., see, Auld, Lawrence W.S. Electronic spreadsheets for libraries. Phoenix, Ariz.: Oryx Press, 1986, and Clark, Philip M. Microcomputer spreadsheet models for libraries: preparing documents, budgets and statistical reports. Chicago: ALA, 1985, as well as most recent issues of Small Computers in Libraries.

3. See for example, Bedford, D.A., "Technical services costs in large research libraries: a preliminary report on the findings of the Samual Lazerow fellowship project." Technical Services Quarterly,6, no. 3:29-48, 1989 as well as Reid, M.T. and Bengtson, B.G., "Report on technical services costs, a preconference to the 1986 ALA annual conference,"' Library Acquisitions, 10:no. 4:231- 
6, 1986, and Auld, op. cit., models for retrospective conversion and bibliographic utility costs.

4. For a conceptual model of cataloging statistics, see, Gillespie, Jim, “Spreadsheets: don't adore your 64K for cataloging statistics," Small Computers in Libraries, vol. 5:no.10, 10-12, November 1985. For a broader discussion of the role of statistical data, among other things, see, Weintraub, D. K., "Using management tools for cataloging discussions," Recruiting, educating and training catalog librarians. Greenwood Press, 1989. p. 375-91. 5. Bommer, Michael R.W. and Ronald W. Chorba, Decision making for library management, White Plains, N.Y.: Knowledge Industry Publications, 1982. Other recent studies of cataloging data include, Godwin, R.P. and Vita, S.H., "Management Information for the CIP program using SAS," Information Technology and Libraries, 7:154-65, June 1988 .

5. Kantor, Paul B. Objective performance measures for academic and research libraries, Washington, D.C.: Association of Research Libraries, 1984.

for faculty/professionals with journal subscription recommendation authority for their institulional library...

If you have read a reprint or photocopy of this article, would you like to make sure that your library also subscribes to this journal? If you have the authority to recommend subscriptions to your library, we will send you a free sample

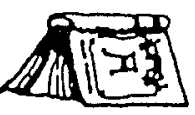
copy for review with your librarian. Just fill out the form below-and make sure that you type or write out cleariy both the name of the journal and your own name and address.

( ) Yes, please send me a complimentary sample copy of this journal:

(please write in complete journal tille here - do not leave blank)

I will show this journal to our institutional or agency library for a possible subscription.

The name of my institutional/agency library is:

NAME:

INSTITUTION:

ADDRESS:

CITY: STATE: ZIP:

Return 10: Sample Copy Department, The Haworth Press, Inc., 10 Alice Street, Binghamton, NY 13904-1580 